WSRC-RP- -89-642

DE9 2010087

\title{
MONITORING OF A RCRA MIXED WASTE MANAGEMENT FACILITY
}

by

Donald E. Gordon, Cary B. Stevens, and R. Cary Tuckfield

Westinghouse Savannah River Company Savannah River Site

Aiken, SC 29808

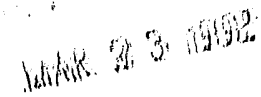

A paper proposed for presentation at the HAZTECH INTERNATIONAL 89 CONEERENCE

Cincinnati, Ohio

September 12-14, 1989

and for publication in the proceedings

The information contained in this article was developed during the course of work under Contract No. DE-AC09-88SR18035 with the U. S. Department of Energy. By acceptance of this paper, the publisher and/or recipient acknowledges the U. S. Government's right to retain a nonexclusive, royalty-free license in and to any copyright covering this paper along with the right to reproduce, and to authorize others to reproduce all or part 


\section{MONITORING OF A RCRA \\ MIXED WASTE MANAGEMENT FACILITY}

\section{INTRODUCTION}

Since startup of the Savannah River Site (SRS) in 1953, solid radioactive waste materials have been disposed of in a centrally located facility known as the Radioactive waste Burial Grounds (Figure 1). These burial grounds comprise three distinct disposal sites which include the original set of burial trenches for solid low level radioactive wastes $(643-G)$, the currently operating Low Level Radioactive Waste Disposal Facility $(643-7 G)$, and the Mixed Waste Management Eacility (643-28G) located within 643-7G (Figure 2). The Mixed Waste Management Facility (MWMF) has been used to dispose of various low level radioactive waste materials just as the other portions of the Radioactive Waste Burial Grounds. Some of the waste materials in the MWMF have been classified as mixed waste under the Resource Conservation and Recovery Act (RCRA).

Because the MWMF contains mixed wastes, a closure plan for the facility was developed and submitted to the South Carolina Department of Health and Environmental Control (SCDHEC) to comply with RCRA requirements. The closure plan was approved by SCDHEC and operations are underway to close 
the MWMF. In addition, a Post-Closure Plan was also submitted to SCDHEC. Tris plan contains a detection monitoring program for assessing the quality of groundwater in the uppermost aquifer beneath the MWMF. This paper discusses the various aspects of the groundwater monitoring program developed to satisfy regulatory requirements for post-closure care and provides some initial results on groundwater quality.

\section{GEOHYDROLOGIC SETTING}

The Savannah River Site lies mostly on the Aiken Plateau as defined by cooke (1936). The Aiken Plateau is bounded by the Savannah and rongaree rivers and is highly dissected and characterized by broad, interfluvial areas with narrow, steep-sided valleys. The area is underlain by a wedge of seaward-dipping unconsolidated, and semi-consolidated sediments.

The Radioactive Waste Burial Grounds are located in an interstream area between two tributaries to the Savannah River, Upper Three Runs Creek to the north and Four Mile creek to the south. The ground surface at these waste burial sites is relatively flat.

Infiltration at these burial grounds moves vertically through the unsaturated zone at a rate of 3 to $7 \mathrm{ft} / \mathrm{yr}$ (as 
determined by tracer tests in the central part of SRS). The depth to the water table in this vicinity is approximately 35 ft. In the saturated zone, water moves horizontally and vertically to outcrop in either Upper Three Runs Creek or Four Mile Creek. A cross section extending between these two streams through the Radioactive Waste Burial Grounds is given in Figure 3. The water table in the vicinity of the MWMF is high because the tan clay layer inhibits the downward movement of water and the low horizontal hydraulic conductivity of the Barnwell Formation does not permit rapid horizontal flow. Measurements in well clusters show that the pressure in sediments in the Congaree Formation is lower than pressures both above and below. Thus, water flows to the Congaree from both above and below, limiting the depth of circulation of water from the MWMF.

\section{NATURE OF WASTE DISPOSAL}

The Mixed Waste Management Facility is located between the $F$ and $H$ Area Separations Facilities (Figure 2) and occupies a total area of 58 acres. Burial trenches in the facility are generally 20 feet deep and 20 feet wide with variable length up to 1,200 feet and nominally 10 feet apart. The MWMF is unlined and there is no leachate collection system. During operation the trenches were backfilled daily to minimize the potential for fire and airborne releases. The MWMF began receiving waste around 1970 . Waste disposal 
in the facility was discontinued in early 1986 when testing results showed that metallic lead disposed in the trenches was a RCRA hazardous material.

Since the MWMF has only recently come under RCRA jurisdiction, records on hazardous waste materials buried at the site are not very complete. It is estimated that wastes placed in the MWMF consisted of job control wastes (i.e., rags, gloves, overalls, etc.l, irradiated scrap metal, equipment, soil, construction debris, spent lithium-aluminum targets, cadmium, silver, tritiated waste oil, scintillation fluids, and lead shielding. Most waste emplaced in the MWMF until April 1984 was packaged in cardboard boxes prior to trench disposal. Subsequently wastes were disposed of in metal containers placed in the trenches. The quantities of known hazardous wastes in the MWMF are given in Table 1.

\section{CLOSURE PLAN}

The closure plan for the MWMF consists basically of compacting the waste materials in the trenches, backfiling to grade, and capping the facility with clay. The specific components of the closure activity are

1) precompaction of waste in trenches

2) backfilling after compaction to a level five feet below the final cover elevations 
3) placement of a three foot, low-permeability $\left(<1 \times 10^{-7}\right.$ $\mathrm{cm} / \mathrm{sec}$ ) clay cap over facility

4) covering the cap with two feet of final cover

5) installing a cap drainage and erosion control system

A schematic diagram of the closure cap is shown in Figure 4. Closure activities at the MWMF began in December 1987 and are scheduled to be completed by December 1990.

\section{POST CLOSURE PLAN}

The plan for care and maintenance of the MWMF after the facility has been clay capped includes an extensive effort to address RCRA groundwater monitoring requirements and provisions for physical security of the facility. Groundwater monitoring activities are discussed in detail in the following section.

\section{GROUNDWATER MONITORING PROGRAM}

A program for detection monitoring of groundwater in the uppermost aquifer beneath the MWMF has been developed and implemented. The several aspects of the groundwater monitoring program are diagramed in Figure 5. They include

1) definition of the uppermost aquifer system

2) specification of groundwater monitoring parameters

3) installation of Point-of-Compliance wells

4) collection and analysis of groundwater samples 
5) establishment of background values for monitoring parameters

6) statistical evaluation of analytical data

7) documentation of results and transmittal to regulatory agencies

Each of these components of the groundwater monitoring program is discussed in turn in the following paragraphs.

\section{Uppermost Aquifer Definition}

South Caroljia Hazardous Waste Management Regulations require that the uppermost aquifer of a hazardous waste facility must be defined. Based on knowledge of geohydrology in the vicinity of the MWMF and RCRA guidance, the uppermost aquifer beneath the MWMF has been defined. It includes all hydrostratigraphic unj.ts that lie between the initial permanent water table and the base of the Congaree Formation (Figure 6). The unconfined water is located some 55 to 75 feet below the ground surface. The water table aquifer recharges a poorly confined aquifer occurring beneath the tan clay unit consisting of two connected but distinct zones. The poorly confined aquifer recharges a lower, more transmissive, semi-confined aquifer which is hydraulically separated from a lower confined aquifer by a clayey aquitard as demonstrated by a reversed (upward) vertical gradient. The primary factor in the definition of the uppermost aquifer 
in the occurrence of a consistently upward vertical gradient observed from the groundwater of the confined aquifer to the groundwater of the Congaree Formation.

\section{Groundwater Monitoring Parameters}

The waste materials disposed to the MWMF were reviewed to develop a list of monitoring parameters that would adequately indicate the presence of hazardous constituents in the groundwater. The list of specific monitoring parameters is given in Table 2. These parameters were selected to establish groundwater quality, contamination, and suitability as a drinking water supply - although no production wells are in the vicinity.

\section{Installation of point-of-Compliance. Wells}

RCRA requirements specify that Point-of-Compliance (POC) wells be installed to provide a geographical boundary at which the monitoring parameters are not to exceed established limits. Thirty-eight POC monitoring wells were installed around the Low-Level Radioactive Waste Disposal Facility (643-7G) which contains the MWMF in 1987-88. These welis were completed as 24 in the water table, 6 in the poorly confined aquifer, and 8 in the semi-confined aquifer. Figure 7 shows the location of these wells. 
The POC wells were installed in accordance with SRS well installation procedures, which meet SCDHEC requirements. All wells were drilled using the hydraulic rotary method. Selected borings were geologically cored and geophysically logged. The casing and screen material for these wells is Trilok polyvinyl chloride (PVC). Schedule 40 PVC is usually specified for these 4 inch diameter wells; schedule 80 PVC is used when unusual or extreme conditions are encountered. Screen slot sizes of ten one-thousands of an inch have been adequate for surrounding geology, however, a sieve analysis is performed as necessary to confirm the selected screen slot size. A concrete pad centered on the well with surface dimensions of 5 feet on a side and a thickness of 6 inches is installed to complete the well construction. The wells are fully developed before they are sampled.

\section{Background water Quality}

Background groundwater quality for a monitoring parameter must be based on data from quarterly sampling of wells upgradient or unaffected by the facility for a period of one year. For the MWME, the background groundwater quality will be based on repilcate samples from BGO-1 and BGO-2 and a 3 year data base of existing measurements from HSB-85 (a nearby wel1). 


\section{Sampling and Analysis}

A sampling and analysis program was developed and implemented at the MWMF. The objectives of this effort were to verify groundwater flow difections in each hydrologic zone by measuring water level elevations in the monitoring wells and to determine groundwater quality through the collection and analysis of representative groundwater samples.

The collection of groundwater samples at SRS follows the approved state and federal procedures. Measures are taken to preserve the chemical and physical integrity of samples prior to aralysis. The recommendations from the EPA in "Test Methods for Evaluating Solid Waste" (SW-846) were followed.

Sample analyses were performed as soon as practical after sampling. Analytical procedures used were consistent with EPA-certified or equivalent methods as described in SW846. All laboratories involved in sample analysis meet professionally acceptable standards for analytical quality control. Stringent chain-of-custody procedures were followed.

The depth to groundwater in all of the monitoring wells is measured prior to purging for sample collection. An 
electronic water level indicator with an accuracy of \pm 0.01 foot was used to determine these groundwater elevations.

\section{Statistical Methods}

There are three issues which will determine the appropriate statistical. methods for data analysis. These issues are

- sampling with true vs "pseudo" replication.

- ignoring the quarter-to-quarter component of variation

- handling the large percentage of measurements below detection

The first issue has to do with collecting the water samples during each quarterly visit to a POC well. Replicate water samples were collected from the well on a given date as required by federal regulations. Sometimes as many as four samples were taken. Each of these samples is considered a replicate. In some instances, however, only subsamples were collected from a single large volume of water drawn from the wel1. The variation among these "pseudo" replicates is not an appropriate estimate of the sample-to-sample variation. Such estimates are more likely to reflect the measurement 
uncertainty of the analytical instrument rather than sampleto-sample variability. Four successive and independent samples drawn from the well would be considered true replicates. But even with true replication, it is not likely that an accurate estimate of the analyte concentration mean and variance for the entire quarter can be obtained on the basis of single day's sampling. A future recommendation is that truly replicate samples be collected from the POC wells at equally spaced time intervals throughout the quarter.

The second issue affecting statistical analyses has to do with the EPA requirement of using a two-sample t-test known as the Cochran's Approximation of the Behrens Fisher test (CABF) or some similar alternative. CABF was originally mandated by the EPA to accommodate the problem of unequal sample variances. According to federal regulations, the mean analyte concentration obtained from each set of replicate measurements in a quarterly sample must be compared to that analyte's corresponding mean background concentration. The mean background concentration comprises approximately 12 quarters of information and varies substantially more than the measurements within a single quarter. In other words, by ignoring the quarter-toquarter component of variation in the POC well sample mean, the need for a $C A B F$ or similar test is artificially imposed. 
A statistical process control method known as the Shewart Chart (Shewart, 1931; Montgomery, 1985) appears to be a more appropriate method than a two-sample t-test. Specification limits on the maximum allowable analyte concentration in the POC well will be explored. Concentrations above this upper bound will be considered as out of compliance. In addition, the cusum chart (Montgomery, 1985) will be used to discover temporal trends in analyte concentration for background and POC wells.

The third and final issue affecting the choice of statistical methods has to do with censored data. There are approximately 40 analytes measured at 41 wells surrounding the perimeter of the MWMF. During 1988, $80 \%$ or more of the concentration measurements for nearly two thirds of these analytes were below the level of detection (LOD). This problem is known as left censoring.

Left censored data are not uncommon to groundwater monitoring programs, but the percentages of unobservable data are typically in the 5-15\% range. Newman, et al. (in press) discuss methods for estimating the mean and variance of left censored environmental data when as much as $50 \%$ of the data are below the LOD. They recommend, however, as do others (Porter et al., 1989) that the actual instrument reading or measurement be reported, even if that measurement is not technically quantifiable and in some cases negative. By 
reporting the actual measurement and not a censored value, some approximation of the variance of the concentrations in the region below the $L O D$ can be obtained and many tecinnical problems in handling the data can be avoided.

The methods described in the above literature citations will be employed to evaluate whether or not post-closure contamination of the ground water on or near the MWMF has occurred.

\section{Regulatoxy Reporting Requirements}

All monitoring wells which comprise the detection monitoring system are being sampled on a quarterly ba:is and tested for the list of monitoring parameters. After appropriate statistical analysis, the data will be submitted to the state regulatory agency after the end of each quarter. per the South Carolina Hazardous Waste Management Regulations.

\section{SUMMARY}

Closure of the Mixed Waste Management Eacility at SRS is underway according to RCRA requirements. A Post-Closure Plan which contains a groundwater monitoring program has been submitted to the state regulatory agency. The detection monitoring of groundwater in the point-of-Compliance wells 
involves several aspects for compliance with RCRA

regulations. In general, there appears to be little

varlation from the RCRA procedures when dealing with a mixed waste faclitty as compared to a strictly hazardous waste facility. Analysis for selected radioactive constituents appears to be the only distinction.

\section{ACKNOWLEDGMENT}

The information contained in this paper was developed under contract No. DE-AC09-88SR18035 with the U. S. Department of Energy.

\section{REEERENCES}

Cooke, C. W., 1936. Geology of the Coastal Plain of South Carolina, U. S. Geological Survey Bulletin 867, Government Printing office, Washington, DC.

Montgomery, D. C., 1985. Introduction to statistical quality Control, John Wiley \& Sons, New York, NY $520 \mathrm{pp}$.

Newman, M. C., M. C. Dixon, B. B. Looney, and J. E. Einder, III (in press). "Estimating the Mean and Variance for Environmental Samples with below Detection Limit Data." Water Resources Bulletin.

Porter, P. S., R. C. Ward, and H. F. Bell, 1988. "The Detection Iimit", Environmental Science and Technology, 22:856-861.

Shewart, W.A. 1931. "The Comparison of Samples with Possibly Unequal Variances", Annals of Eugenics, $9: 174-180$. 
TABLE M

KNOWN HAZARDOUS WASTES IN THE WMT

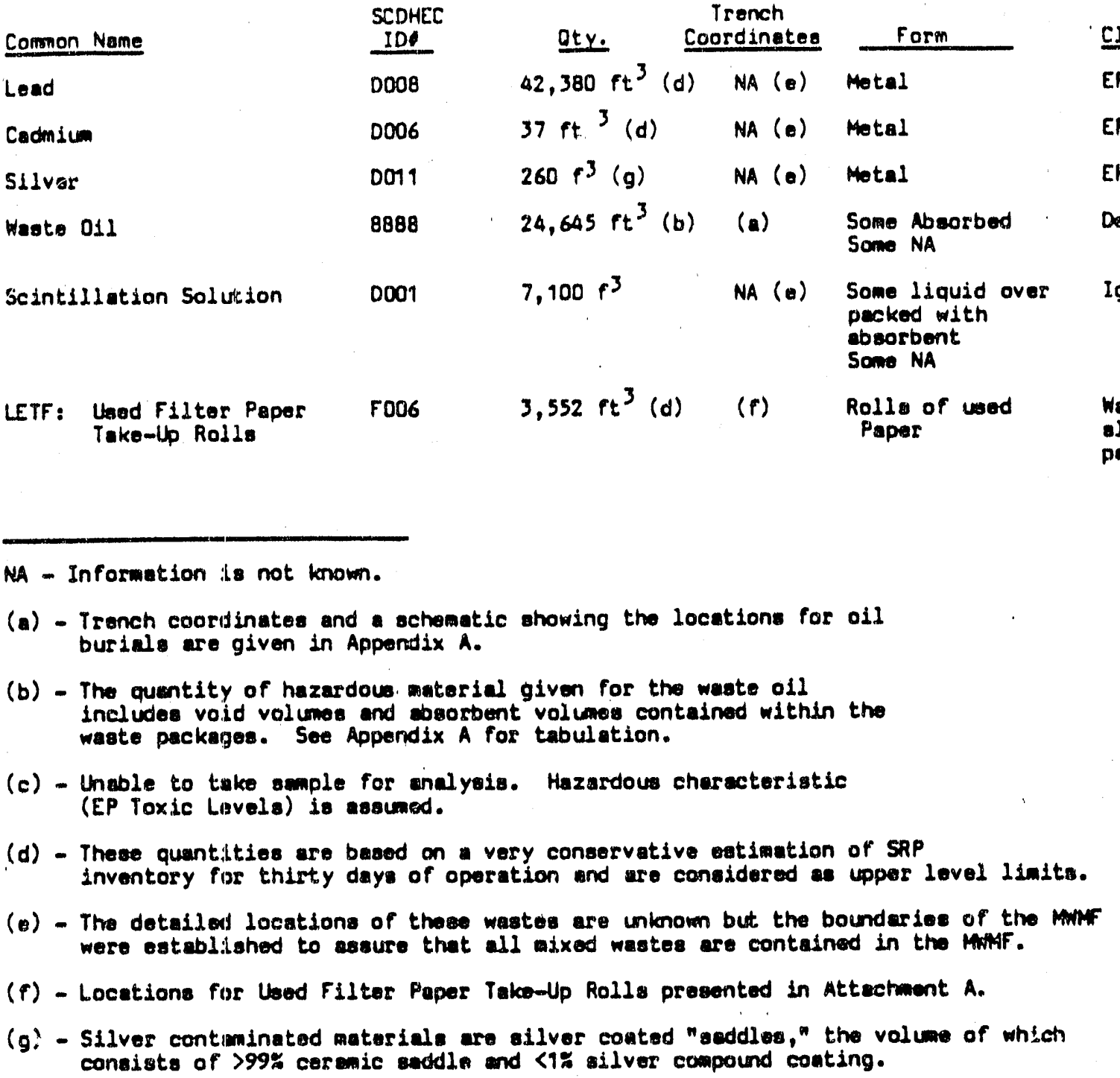

Beais of

Hazardous

Classification

EP Toxic $>5 \mathrm{mg} / \mathrm{l}$

EP Toxic $>1 \mathrm{mg} / \mathrm{l}$ (c)

EP Toxic $>5 \mathrm{mg} / 1$ (c)

Definition

Ignitable, Flashpoint $<940^{\circ} \mathrm{F}$

Wastewater treatment sudge (F006) may be on peper

\section{CHARACTERISTICS OF TRITIATED WASTE OIL}

\begin{abstract}
Chlorine Content
Hout Content

Sulfur Content

Arsende Content

Barisa Contont

Cadiniun Content
\end{abstract}

$450 \mathrm{mg} / 1$

$19,519 \mathrm{BTU} / \mathrm{Ib}$

0.20 weight percent oulfur

<C. OS $\mathrm{mg} / 1$

$2.50 \mathrm{mg} / 1$

<0.01 mg/ 1 
TABLE 2

DETECTION MONITORING PARAMETERS

MWMF

Comprehensive Analysis

\begin{tabular}{|c|c|c|}
\hline $\mathrm{Cl}$ & Cr & $\begin{array}{l}\text { Endrin } \\
\text { Lind ane }\end{array}$ \\
\hline $\begin{array}{l}\text { Fe } \\
\mathrm{Mn}\end{array}$ & $\begin{array}{l}\mathrm{F} \\
\mathrm{Pb}\end{array}$ & \\
\hline Phenol: & Hg & Methoxychlor \\
\hline $\begin{array}{l}\mathrm{Na} \\
\mathrm{SO}_{4}\end{array}$ & $\begin{array}{l}\mathrm{NO}_{3} \\
\mathrm{Se}^{2}\end{array}$ & $\begin{array}{l}\text { Toxaphene } \\
2.4 \mathrm{D}\end{array}$ \\
\hline $\begin{array}{l}\mathrm{pH} \\
\text { Conductivity }\end{array}$ & $\begin{array}{l}\mathrm{Ag} \\
\mathrm{Al} \text { pha }\end{array}$ & $2,4,5$ IP (silvex) \\
\hline & $\begin{array}{l}\text { Bera } \\
\text { Ra }\end{array}$ & (Iurbidity)(1) \\
\hline As & $\begin{array}{l}\text { Benzene } \\
\text { Toluene } \\
\text { Xylene }\end{array}$ & \\
\hline
\end{tabular}

Note: (1) Turbidity is used to evaluate ambient condition ar each well location relative to well performance only. 


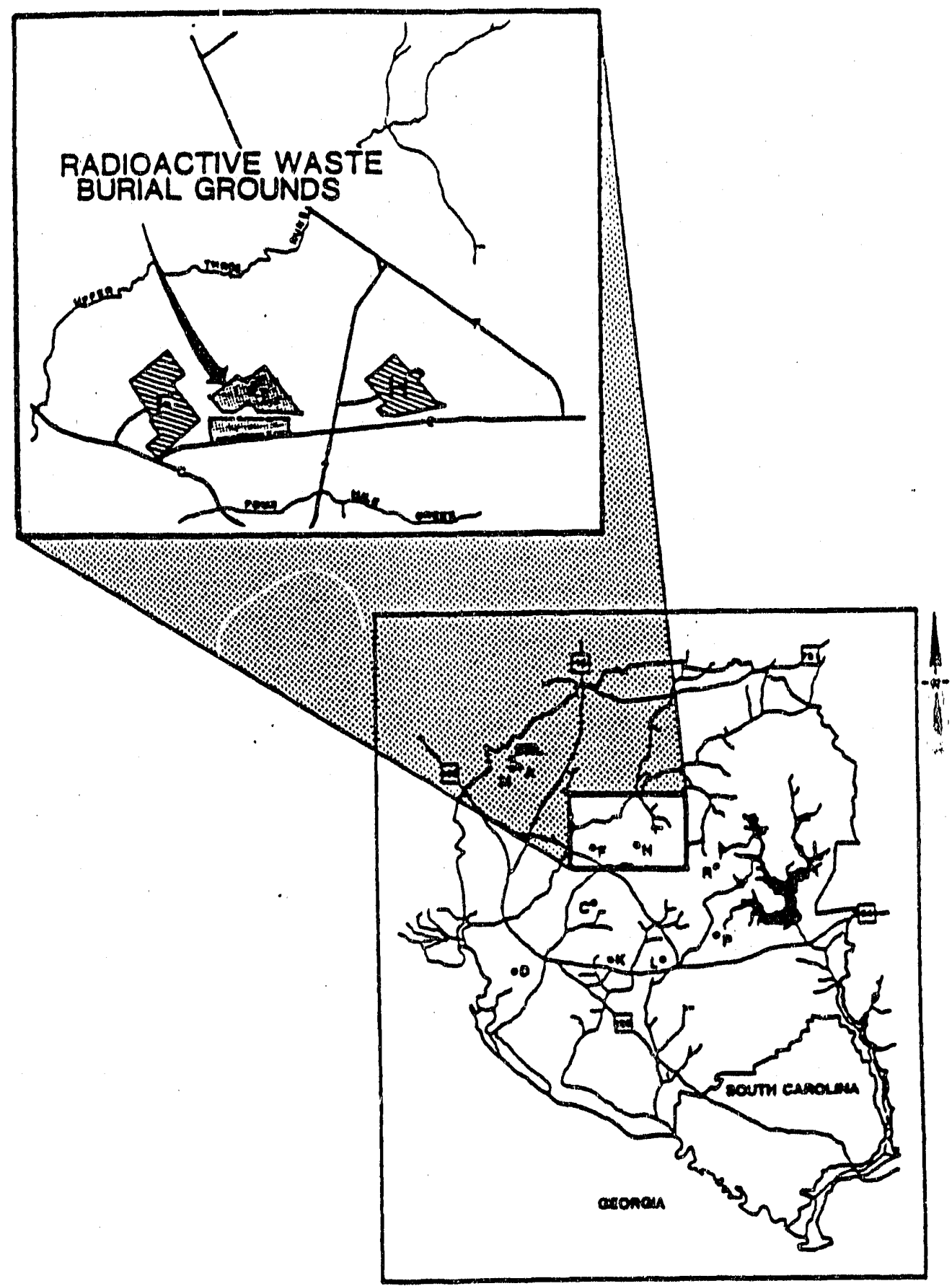

FIGURS 1. Location of the Bndioactive Waste Burial Gromonds 


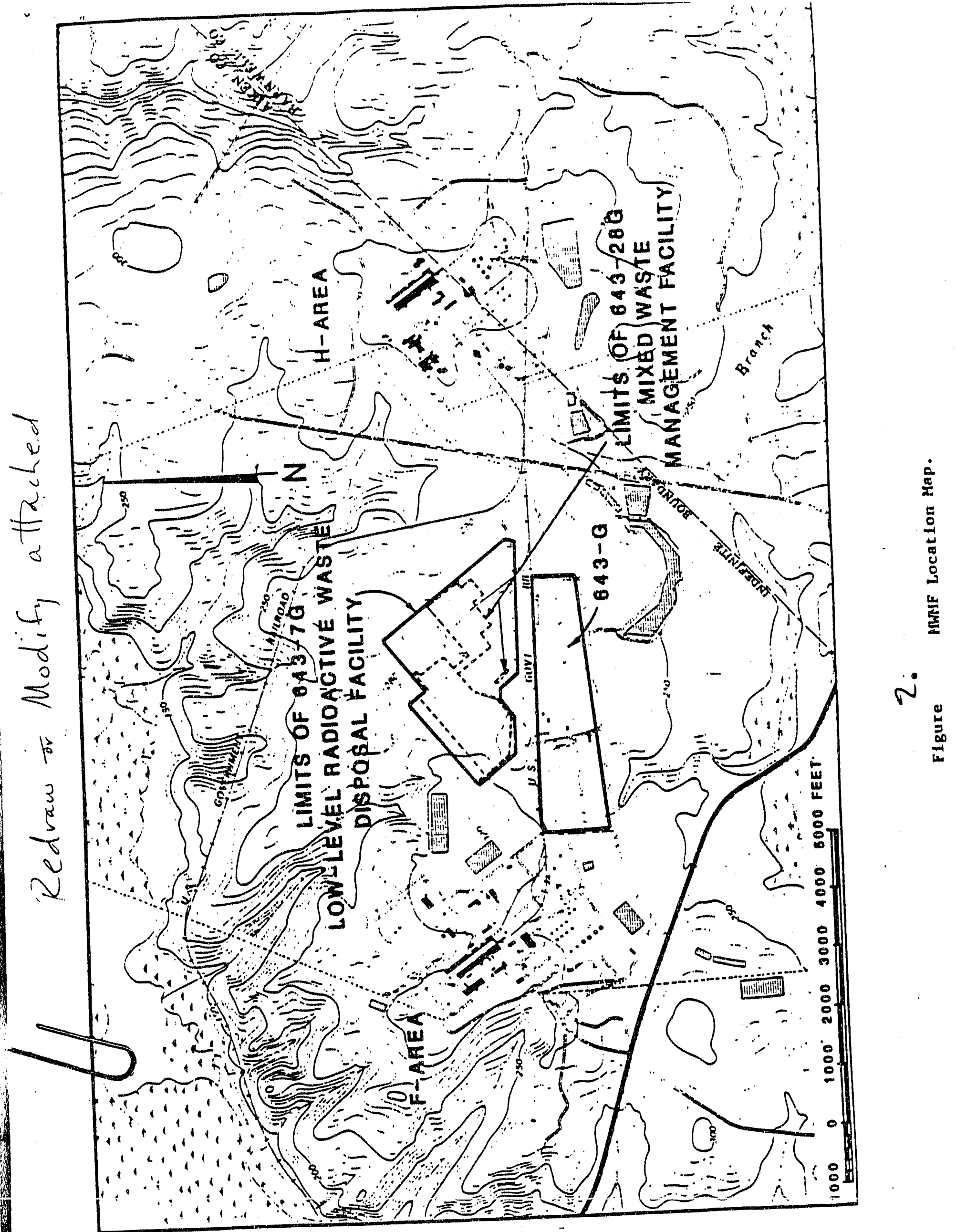




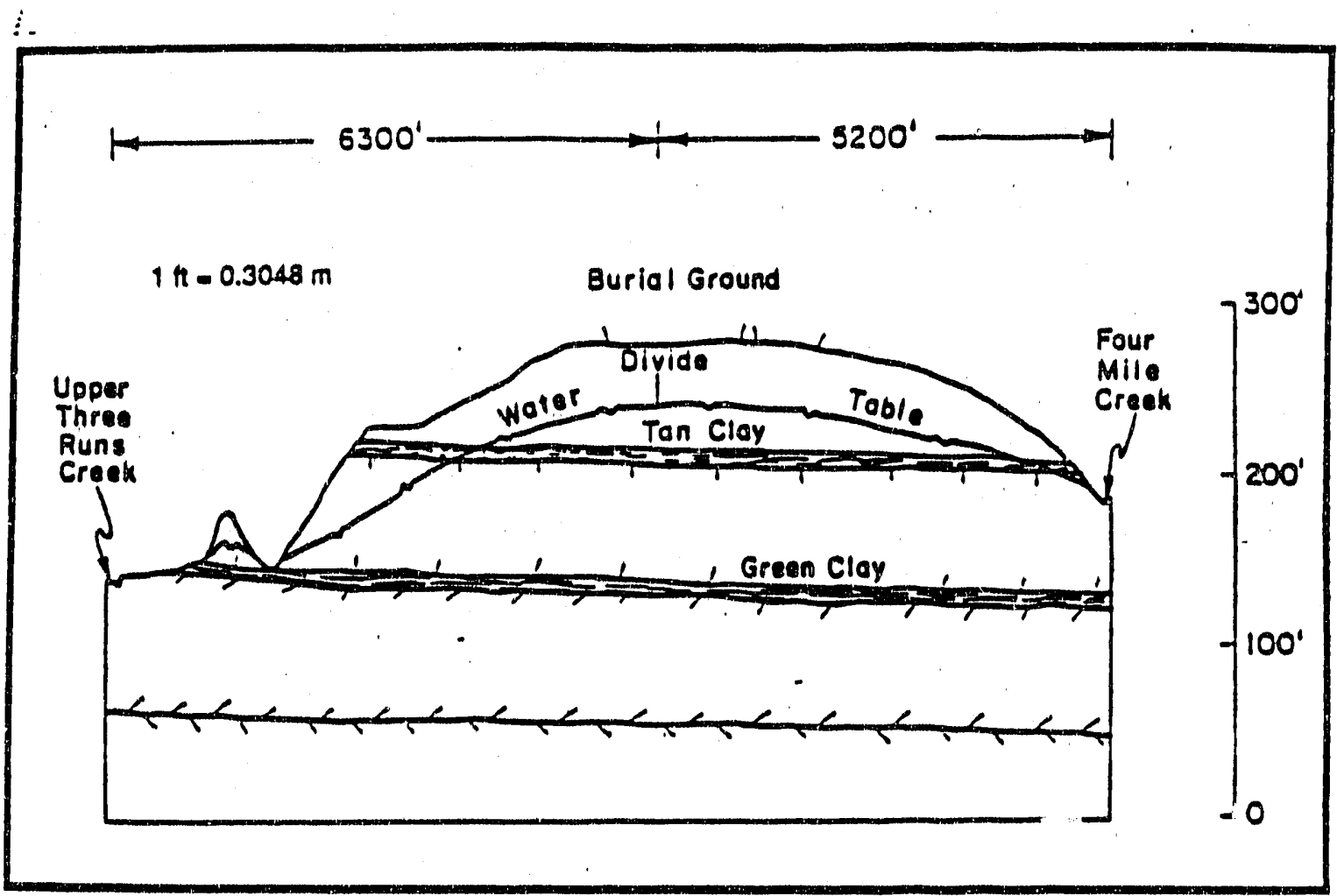

FIGUBs 6. Crosa Section Through the Burinl Ground Showing Displacement
of Water-Table Divide Towerd Pour Mile Creek 


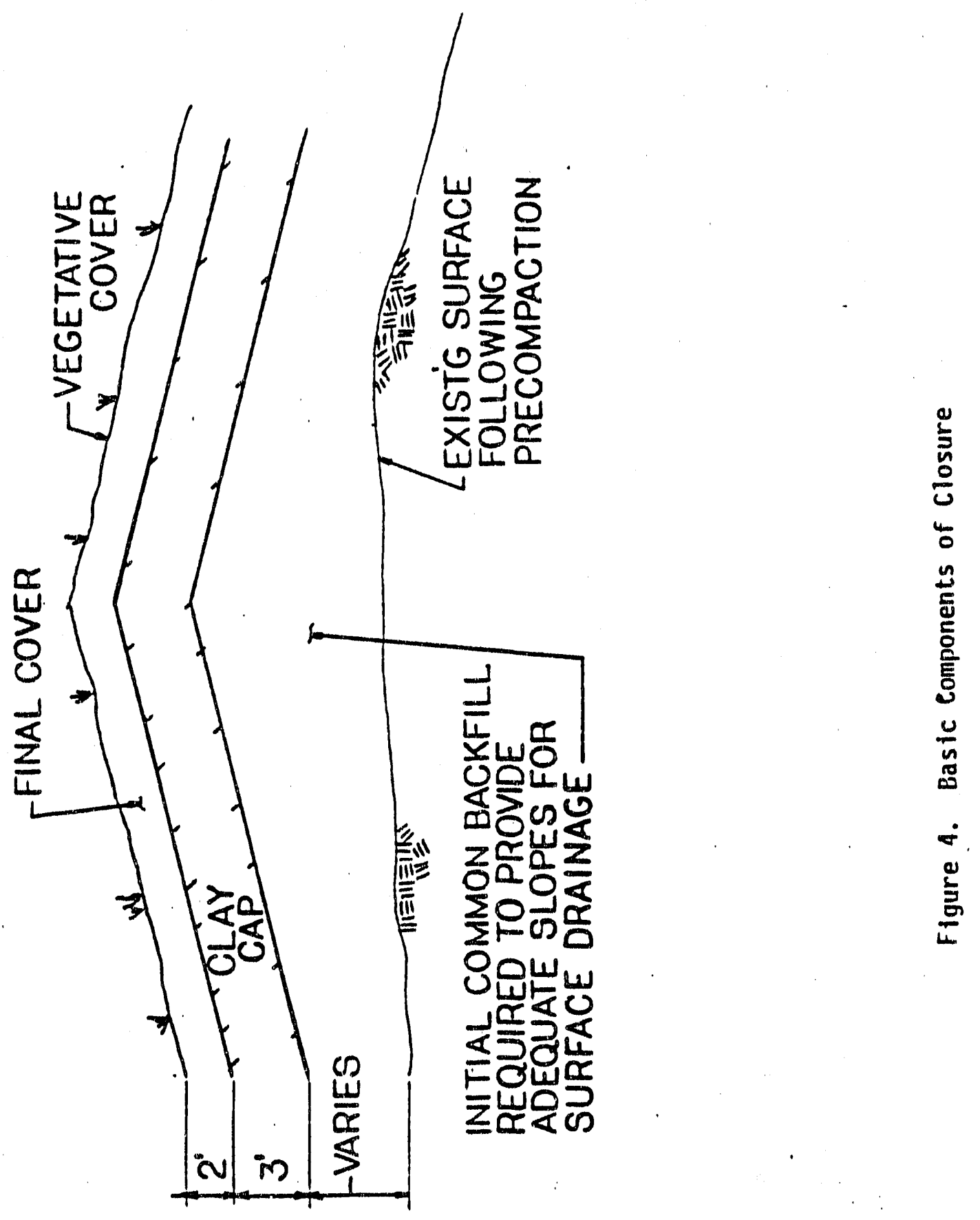




\section{Define Uppermost Aquifer System}

Specify Detection Monitoring Parameters

Install POC Wells

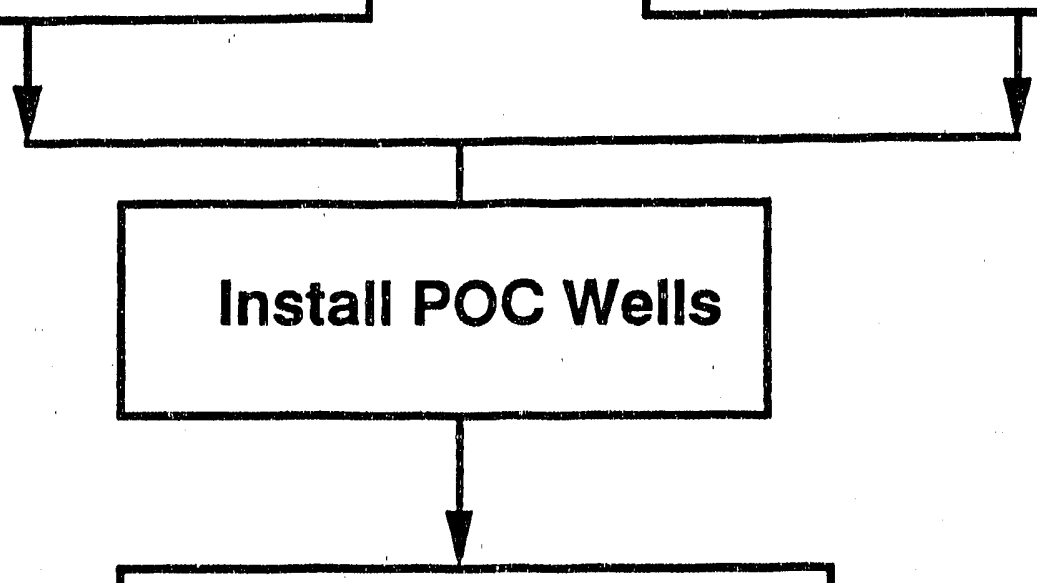

\section{Sample and Analyze} Groundwater

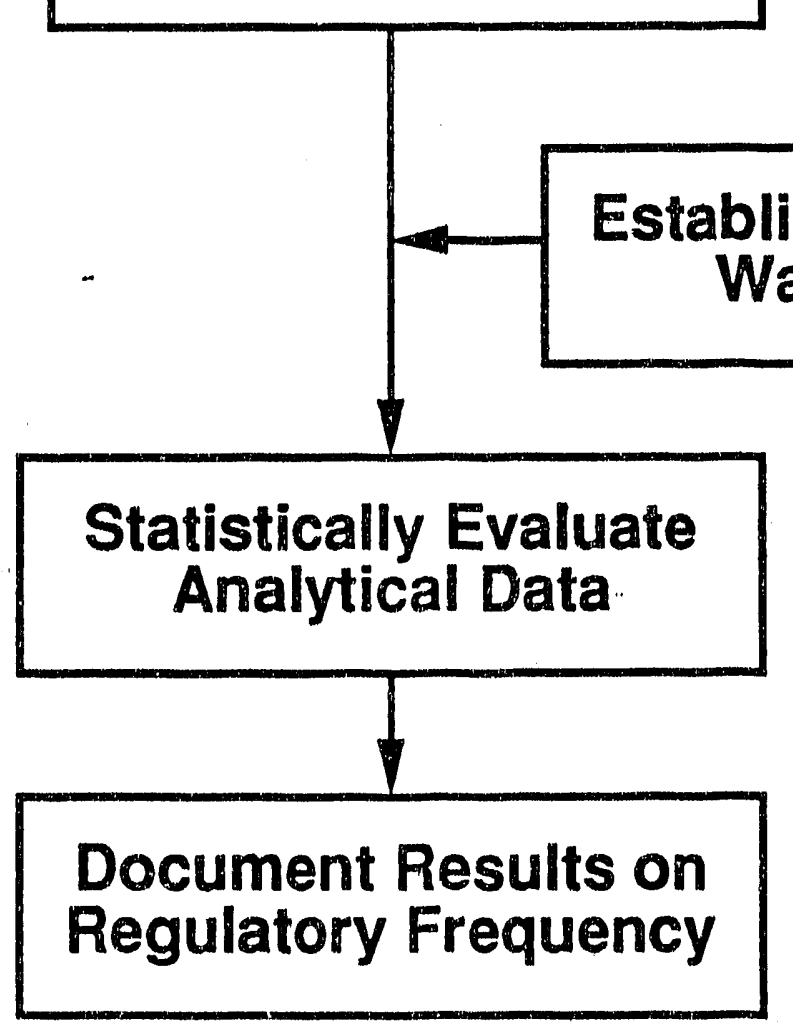

FIGURE 5. Components of Groundwater Monitoring Program 


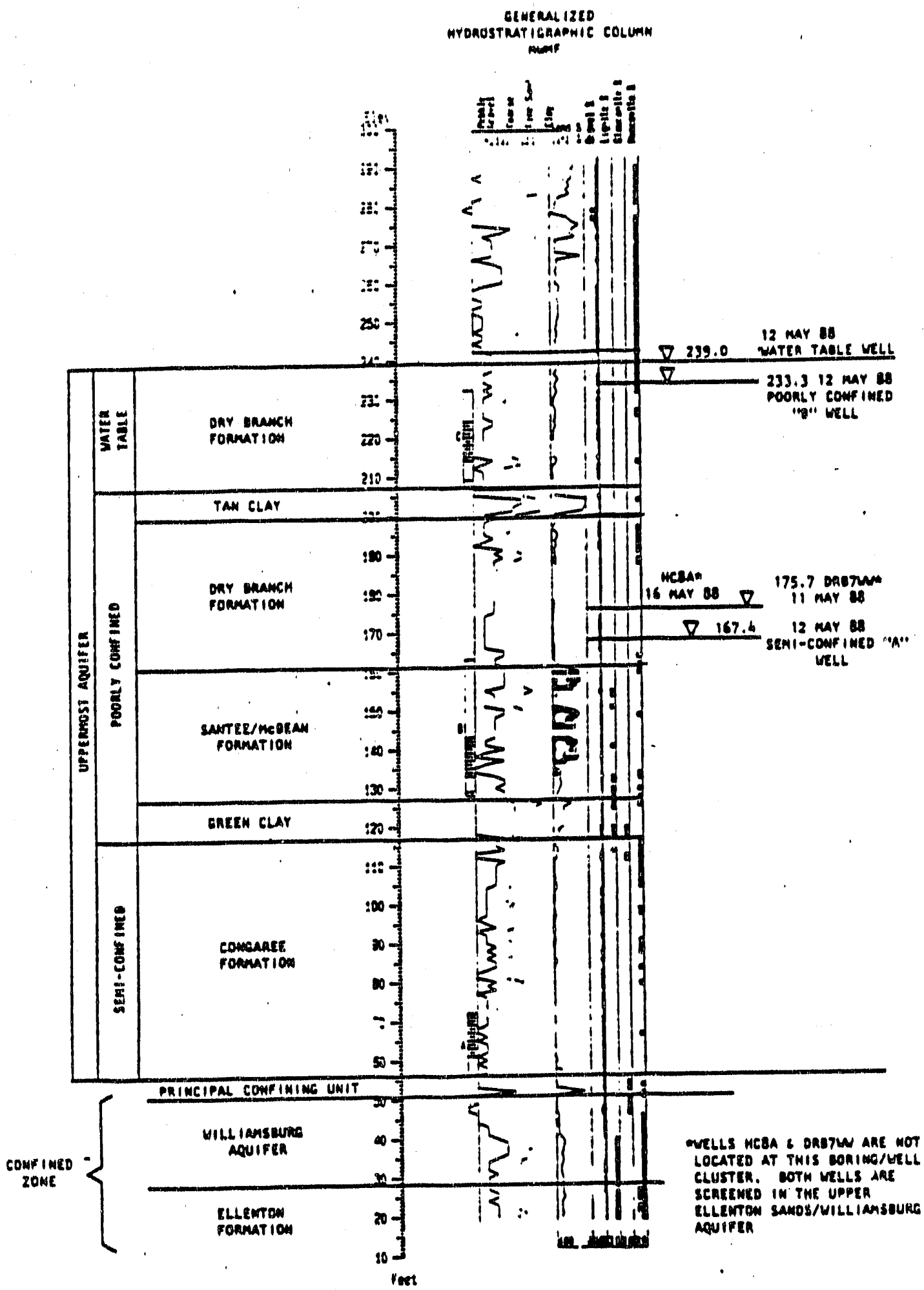

Figure 


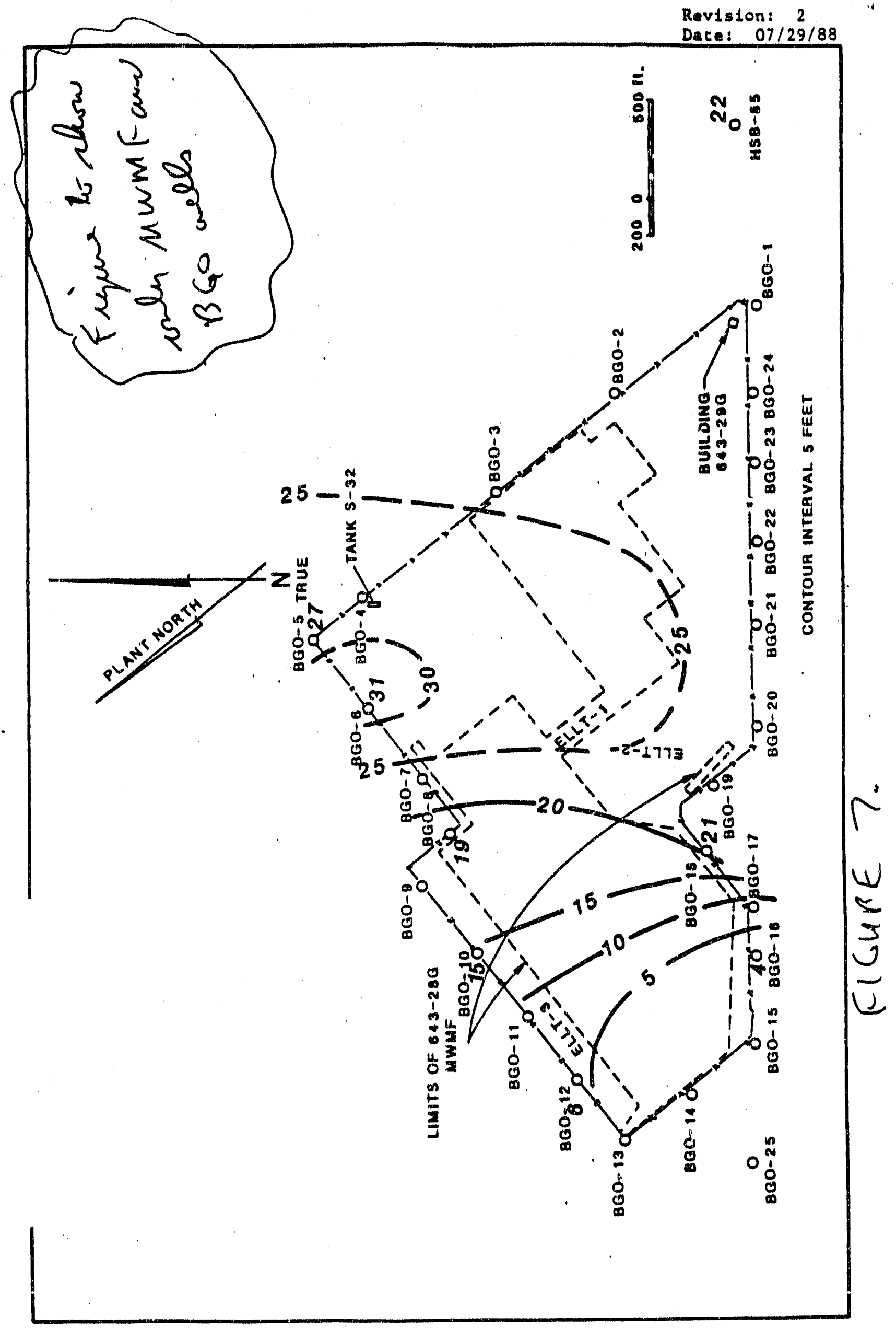



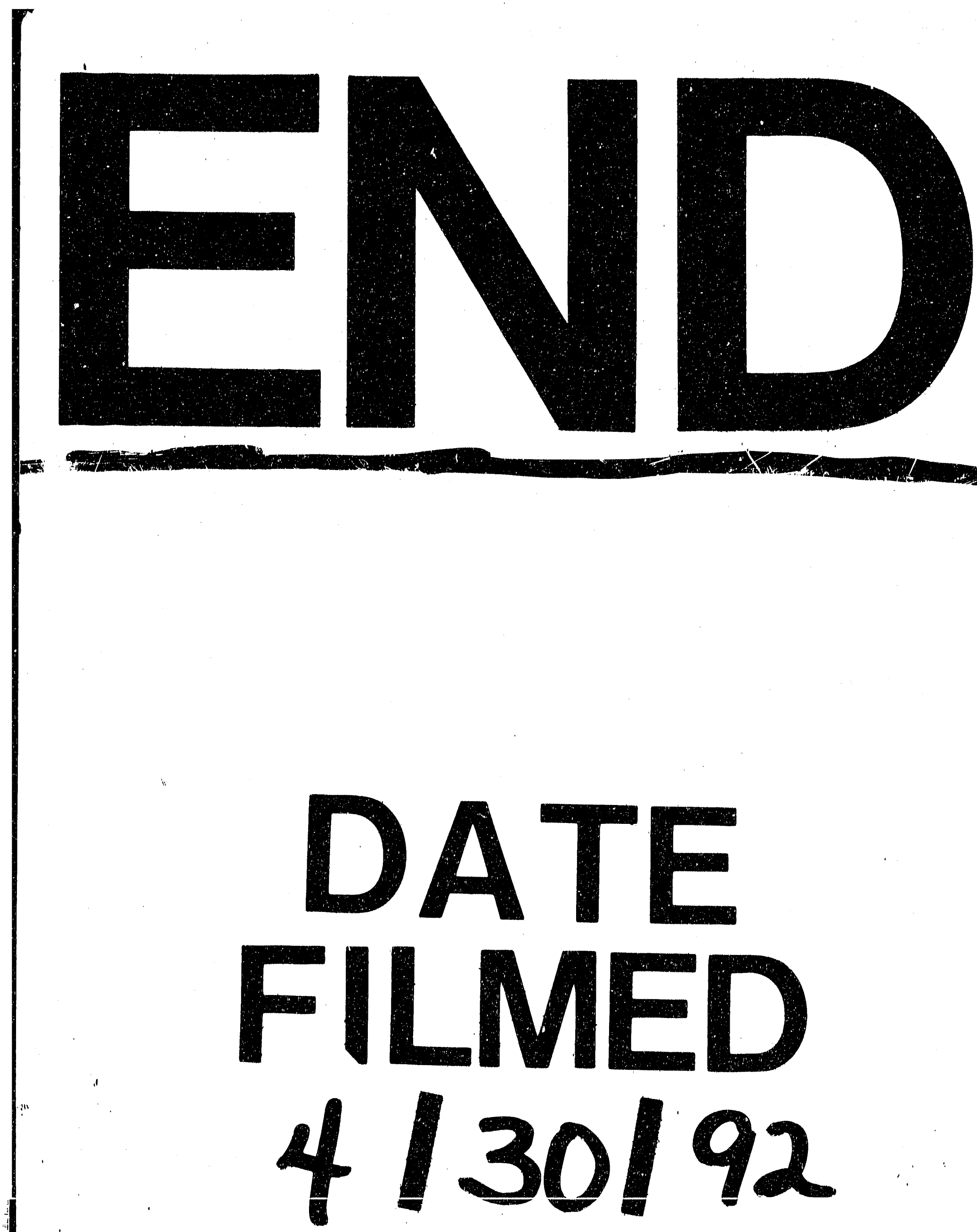


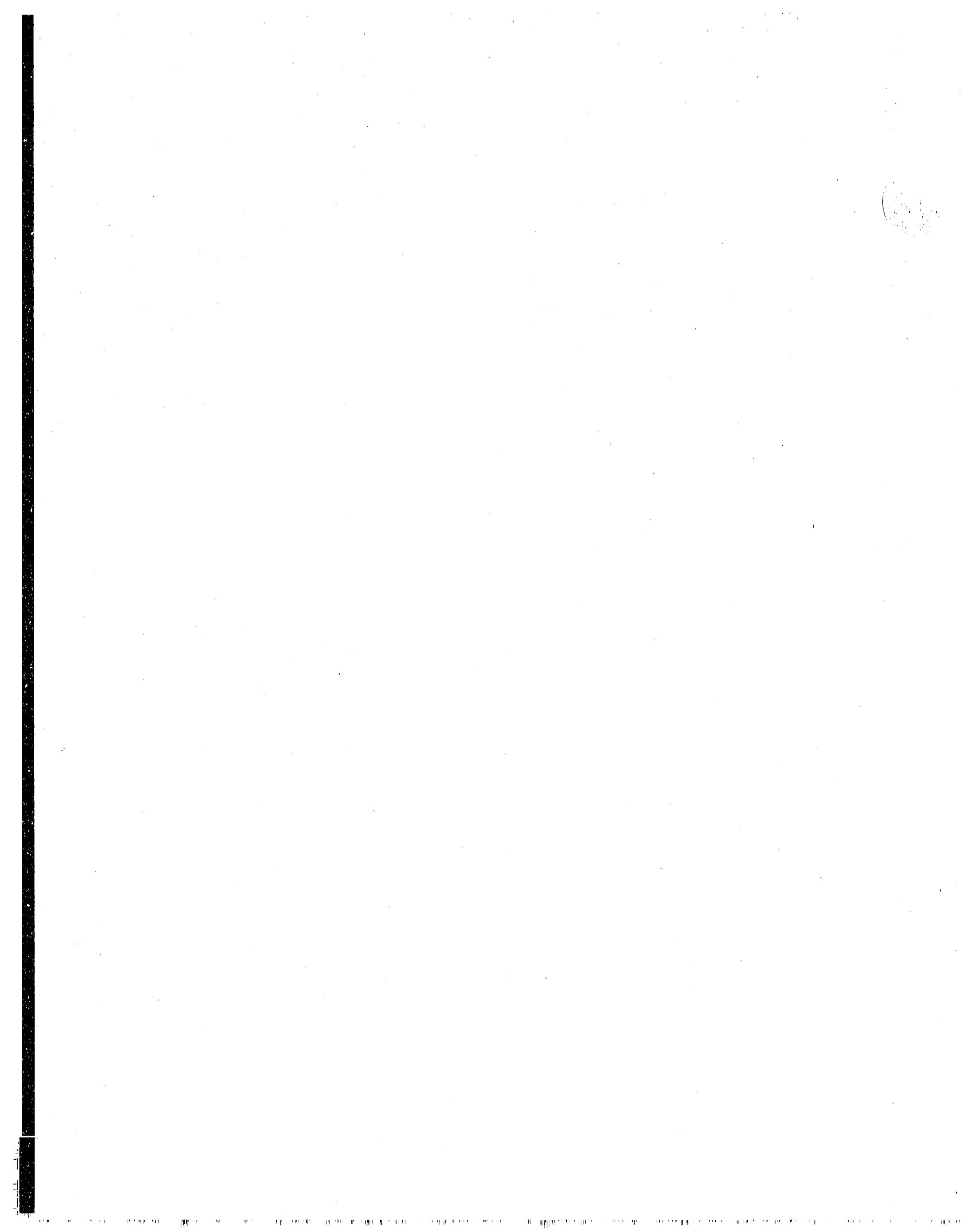

